\title{
REJUVENATING THE SHOPHOUSE: CONSERVATION OF HISTORICAL BUILDINGS IN PENANG'S UNESCO WORLD HERITAGE SITE
}

\author{
ZAHARI ZUBIR, KOH JING HAO, NOR HAYATI HUSSAIN \& PRINCE FAVIS ISIP \\ School of Architecture, Building and Design, Taylor's University, Malaysia.
}

\begin{abstract}
Conservation of shophouses, the architectural heritage of the colonial past in Penang's UNESCO World Heritage Site, is subjected to strict conservation regulations and guidelines imposed and enforced by the local authority. The goal of the conservation effort is to add value to the dilapidated structures in order for them to remain relevant and economically viable while maintaining the historical essence of the site. Sadly, because of erroneous conservation treatments, many have failed to achieve the intended goals. This article explores the regulations and processes involved and the challenges faced by building owners in conserving the shophouses. The significance of the study stem from the crucial need to deal with the issues involved in the conservation of heritage buildings within the rapid economic growth and transformation of Penang's UNESCO World Heritage Site urban fabric. The study employs theoretical and analytical approaches as its methodology. This article discusses the initiatives of three building owners in conserving shophouses into boutique hotel, museum and office, each originally of different purposes. Each of them applied adaptive reuse conservation strategy, with similar intention of rehabilitating the buildings for a more viable and current usage while maintaining their historical value and character. This article will serve as a reference for the local authorities, architects, designers, conservators and the public when embarking on projects of a similar nature in the future.
\end{abstract}

Keywords: adaptive reuse, conservation, Penang, shophouses, UNESCO.

\section{INTRODUCTION}

The cities of George Town and Melaka, Malaysia, were inscribed as a UNESCO World Heritage Site (WHS) on 7 July 2008. Currently, George Town is the capital city of the state of Pulau Pinang (Penang), Malaysia (Fig. 1). The city begins as the first British Straits Settlement along the Straits of Melaka in the late 18th century and over the last two centuries went through transformation from a swampy frontier to a bustling trading post [1].

The architecture of the city is shaped by the existence of the numerous ethnicities that had settled over the centuries: Chinese, Indians, Arabs, the local Malays, Achenese, Siamese, Burmese and Europeans. The city boasts a rich collection of historic building in various styles. They include the Indo-Malay Palladian Style, Anglo-Indian Bungalows, Early Shophouses, Early Transitional Style, Early Eclecticism Shophouse, Sino-Anglo Bungalows, Neo-Classical Style, Art Deco Style, Early Modern Style, as well as numerous religious buildings such as mosques, churches, Chinese and Hindu temples [1]. The heritage site of George Town is divided into two zones, i.e. the core zone and the buffer zone. The area of the whole of the heritage zone is 259.42 hectares, with the core zone comprising $42.16 \%$ or 109.38 hectares and the buffer zone comprising $57.84 \%$ or 150.04 hectares [2]. The WHS Outstanding Universal Values (OUV) that had been attributed to the city is Criteria (ii), (iii) and (iv) [3]. 


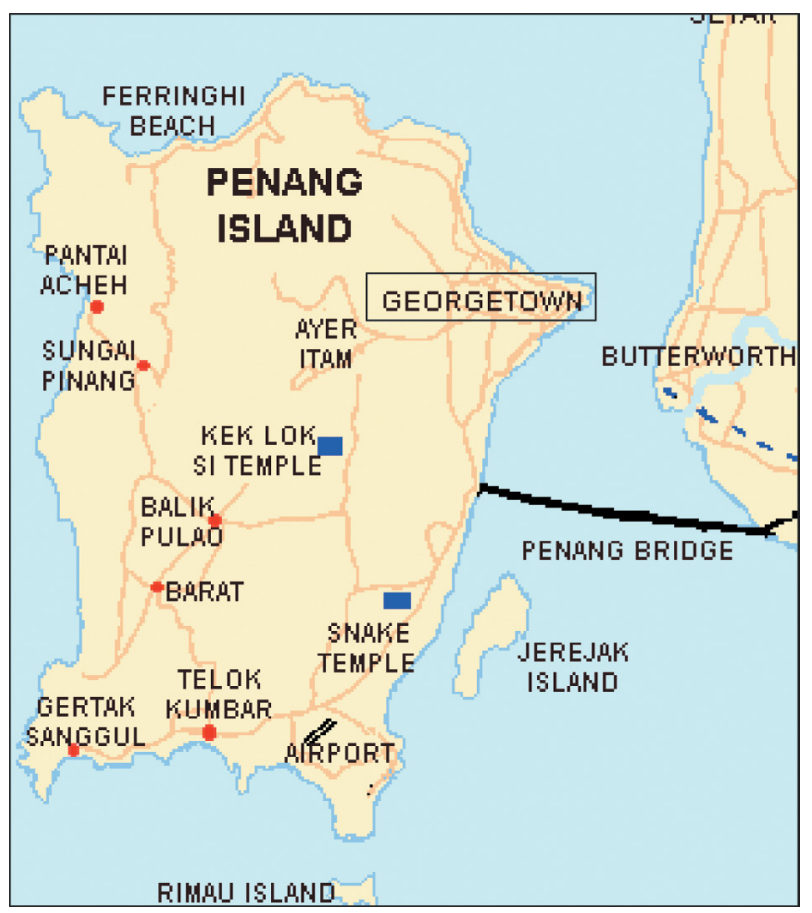

Figure 1: Location of George Town within the island of Penang.

\section{STATUTORY APPROVAL FOR DEVELOPMENT IN GEORGE TOWN}

As is the case throughout Malaysia, any building construction and development will require submission of plans and for the plans to be approved before any form of construction can commence. In Malaysia, typically, a building development comes under the purview of several acts of government, namely the Local Government Act 1976, the Street, Drainage and Building Act 1974, the Town and Country Planning Act 1976 and the Uniform Building By-laws 1984. For development involving heritage, the list also includes the National Heritage Act 2005.

Under the local authority, developments are also subjected to various legal requirements such as the Structure Plan for Penang State 2020, the George Town Special Area Plan 2016 (SAP) and the Planning Policy and Development Zone Plan 1996. For development involving heritage, the list includes the Regulations for Conservation Areas and Heritage Buildings, Municipal Council of Penang Island (MBPP) 2009 and The Heritage Enactment of Penang State 2011.

\subsection{Procedures and processes}

A typical procedure for any development in Malaysia is that the proposed development needs to first obtain Planning Permission and after that Building Plans approval. Both submissions are to the local authority where the development is situated. This also applies to renovations of buildings and other similar activities such as conservation work.

In the case of George Town, the local authority is the Majlis Bandaraya Pulau Pinang or MBPP. In line with the inscription of George Town as a UNESCO WHS in 2008, the State Planning Committee of Penang has prepared and approved the Heritage Management Plan 

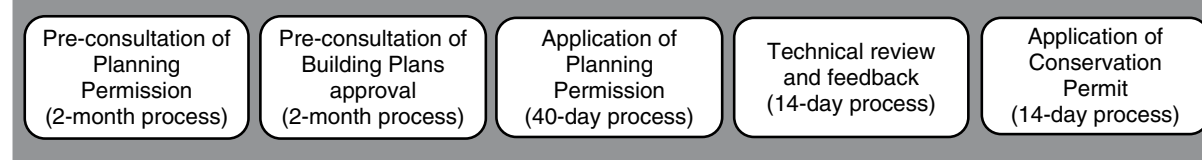

Figure 2: Process flow for conservation works approval Source: Adapted from Heritage Department MBPP, Customer Charter.

to be used for the management and handling of all aspects relating to the heritage site for the purpose of preserving and rehabilitating its OUVs. Under this plan, MBPP has formed the Heritage Conservation Department in 2011 for the purpose of scrutinizing, monitoring, commenting and enforcing all development activities which involve the heritage site [4]. For a development involving the WHS, the plan submission process is as per Fig. 2 [5].

\subsection{Application for Planning Permission}

The technical departments that are involved in the approval process of Planning Permission include the MBPP's One Stop Center, MBPP's Heritage Department, MBPP's Development Planning Department, Georgetown World Heritage Incorporated Penang and the National Heritage Department (a federal department). Among the documents that are required for the application of Planning Permission are a set of plans, Heritage Impact Assessment (HIA) report, survey plans and landownership title [6].

\subsection{Application for Building Plans approval}

The department that is involved in the approval process is the MBPP's One Stop Center. Among the documents required for the submission are Building Plans, Planning Permission approval letter, MBPP's Heritage Department approval letter, survey plans and landownership title. Other relevant technical departments and service provider that requires consultations and submission for approval may include the Fire and Rescue Department, Public Works Department and service providers for sewage treatment, water supply, electrical supply, drainage and irrigation, telecommunications, etc. [7].

\subsection{Problem statement and methodologies}

With the legal and procedural backdrop mentioned earlier, businesses and building owners in George Town will have to deal with the various requirements in order to comply with the needs of maintaining the UNESCO status. This article seeks to identify the challenges experienced by owners by studying shophouses that have either been converted, undergoing renovations or undergoing stages of approval. Recently implemented procedures have increased the pressures faced by the owners. For example, the 1 September 2016 deadline to submit submission of documents to legalize existing hotel operations. Owners are required to submit Heritage Impact Statement. Once approved, owners need to submit for Building 
Plans approval. Also, starting 1 September 2016, for non-hotel category, owners are required to submit HIA. Once approved, owners need to submit for Building Plans approval. The 2016 gazetting of the SAP also added to the pressure.

As for methodology, interviews and on-site observations were conducted to obtain firsthand account of the processes and challenges. Documentation in the form of photographs and drawings indicating changes made by the owners were undertaken.

\section{SHOPHOUSE TYPOLOGY}

The shophouse typology is an urban building form developed over 200 years, with historically, a shop or business premise on the ground floor and accommodation quarters above. They are normally arranged in rows or terraces with an interconnecting veranda way called a five-foot way at the front. They are usually two or three storeys high with each unit sharing side party walls. Plans are usually deep but with narrow frontage. They were constructed using clay bricks and timber [8]. In George Town, there are about 7,000 shophouses and they are categorized under six main styles: Early Penang Style (1790s-1850s), Southern Chinese Eclectic Style (1840s-1910s), Early Straits Eclectic Style (1890s-1920s), Late Straits Eclectic Style (1910s-1930s), Art Deco Style (1930s-early 1960s) and Early Modern Style (1950s-1970s) [9]. Within the WHS there are altogether 5,013 buildings of various typologies, 2,569 within the core zone and 2,444 within the buffer zone [2].

Since the inscription of WHS, many building owners converted their building into other usage such as cafes, boutique hotels, museums and offices. Recently, because of the implementation of the various regulations and procedures by MBPP, many owners failed to comply with the requirements, resulting in confrontations and dispute over what is the best way to conserve and to develop. As of 1 December 2016, only 20 out of 100 shophouses that have been identified had received approval, while the rest are either not approved or have not even submitted application for business operation (Fazil, M.A., Personal communication, November 2016, Technical Officer, Heritage Department, the Municipal Council of Penang (MPPP), Malaysia).

\section{CASE STUDY}

Three shophouse renovation projects have been selected as case studies and are discussed in the following section. Figure 3 provides the location of the buildings. Following that Table 1 compares the characteristics of the buildings.

\subsection{Case study 1: Dr. Sun Yat Sen Museum and Research Center,} No. 120, Armenian Street

Built around 1880, lot no. 120 is located in the core zone of the WHS. This building showed the architectural characteristics of the Southern Chinese Eclectic style which was brought over to Malaya around the 1840 s by Chinese immigrants from Southern China, mainly Guangdong and Fujian provinces. Currently used as a museum, this building had played a very significant role in the history of the Republic of China. The founding father of Modern China, Dr. Sun Yat Sen, visited Penang several times in an effort to persuade the overseas Chinese to support the revolution movement to overthrow the Qing government. The building was used as the command base of Tongmenghui (Chinese United League) for this purpose. Among the historical events held at the building are; The Penang Philomatic Union, a reading club that served as propaganda, recruitment and registration centres for the Tongmenghui, moved to this building on 23 May 1909, an emergency meeting chaired by Dr. Sun Yat Sen at 


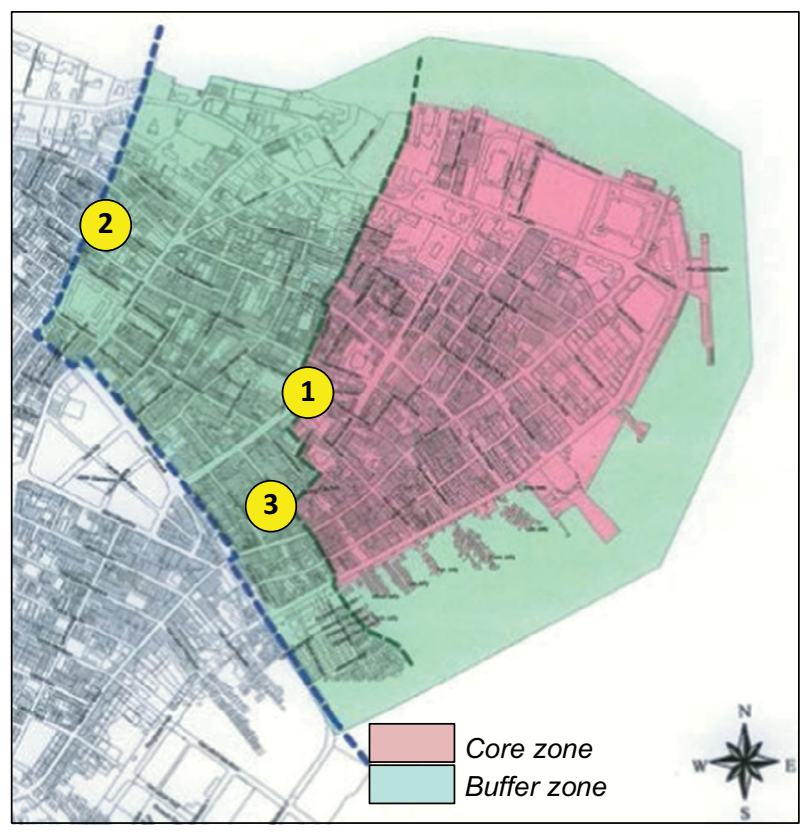

Figure 3: Case studies' locations and Penang's UNESCO WHS zones.

the formal dining area to raise fund for the Second Guangzhou Uprising and the founding of Kwong Wah Yit Poh as the main revolutionary newspaper of Tongmenghui [10]. The building is currently under the custody of Ms. Khoo Salma Nasution. Restoration work of the building was carried out in 1993 and was completed in 1994. Currently, the building is undergoing another process of converting the upper part of the building into a research centre.

\subsection{Case study 2: Penaga Hotel, Hutton Street, Transfer Street and Clarke Street}

Built in the 1920s and renovated after the Second World War, the building comprises three rows of double-storey terraced houses and shophouses fronting three main streets; Hutton, Transfer and Clarke. Transfer Street was named after the event of the transfer of Strait Settlement from Indian office to Colonial office in London in 1867. Hutton Street was named after Dr. James Hutton, one of the first doctors in Penang, who arrived in 1805 . He is the first civilian medical practitioner in the then British Malaya. Clarke Street was named after Sir Andrew Clarke, the governor of the Straits Settlements from 1873 to 1875 [11]. The shophouses were acquired by the current owner in 2008. He renovated and converted them into a 45-room boutique hotel called Penaga Hotel and art gallery, which is currently in operation. The hotel gets its name from Tanjong Penaga or Penaga Cape, the old name for George Town. The cape was named after the Penaga Laut tree which once grew in abundance there.

\subsection{Case study 3: Nos. 3, 5 and 7 Fish Lane (boutique hotel)}

Built in 1929, lot nos. 3, 5 and 7 are the typical shophouse along Fish Lane and are categorized as Late Straits Eclectic Style. The Fish Lane is a small lane off the Lower Beach Street in George Town. During the mid-19th century, the street served as the drying yard for salted 
fish, hence the 'Fish Lane' [12]. Beach Street used to be the actual beach line. As such Fish Lane was a convenient location for drying of fishes. Today it is a small and quiet lane, lined with old colonial shophouses. In 2012, the three lots were sold and were earmarked for conversion to boutique hotel.

Table 2 summarizes the information on the three case studies.

Table 1: Comparison of the three case studies' architectural characteristics.

\begin{tabular}{ll}
\hline Building & Picture \\
\hline Case study 1 \\
Dr. Sun Yat \\
Sen Museum \\
and Research \\
Center
\end{tabular}

Architectural characteristics

- Southern Chinese Eclectic Style

- Architectural features include U-shaped terracotta roof tiles on timber battens from ridge to eaves, roof ridge and overhanging pitched roof with stepped terracotta soffit

- On the upper floor, column head (Chi Tou), timber louvered shutters and low brick wall with indented panel and green ceramic air vents, and decorated panel or louvered below wall plate

- On the lower floor, two square shutter openings and air vents above, and brick wall with central comb door and solid timber door

- Five-foot way; terracotta floor tiles

$\begin{aligned} & \text { Case study } 2 \\ & \text { Penaga Hotel } \\ & \text { (45-room } \\ & \text { hotel) }\end{aligned}$
$\begin{aligned} & \text { Mix of the Late Straits Eclectic Style and } \\ & \text { Art Deco } \\ & \text { The Art Deco elements can be seen at } \\ & \text { the banded first floor spandrel beams and } \\ & \text { banded column surfaces } \\ & \text { Architectural features include U-shaped } \\ & \text { terracotta roof tiles } \\ & \text { On the upper floor, wooden louvered } \\ & \text { shutter windows } \\ & \text { On the lower floor, butterfly-shaped } \\ & \text { Chinese air vents, timber windows with } \\ & \text { iron bars, curved timber ventilated door } \\ & \text { and brick wall terracotta floor tiles } \\ & \text { The newly added second and third floors } \\ & \text { matched the existing lower floors }\end{aligned}$




\begin{tabular}{|c|c|c|}
\hline Building & Picture & Architectural characteristics \\
\hline $\begin{array}{l}\text { Case study } 3 \\
\text { Ongoing } \\
\text { renovation } \\
\text { work for } \\
\text { boutique hotel } \\
\text { (as of January } \\
2016 \text { ) }\end{array}$ & & $\begin{array}{l}\text { - Late Straits Eclectic Style } \\
\text { - Architectural features include U-shaped } \\
\text { terracotta-shaped roof tiles } \\
\text { - On the upper and lower floor, 3-D } \\
\text { decorative plaster wall with Chinese- and } \\
\text { European-influenced decoration, dado } \\
\text { panels below windows with Majolica } \\
\text { tiles, central carved door with solid } \\
\text { inner door, decorated air vents, granite } \\
\text { edge block entrance step and full-length } \\
\text { louvered windows } \\
\text { - Five-foot way; cement tiles }\end{array}$ \\
\hline
\end{tabular}

Source: Author, 2016.

Table 2: The three case studies' information summary.

\begin{tabular}{|c|c|c|c|c|c|}
\hline Building & Location & Original use & Current use & $\begin{array}{l}\text { SAP } \\
\text { category* }\end{array}$ & $\begin{array}{l}\text { WHS } \\
\text { zone }\end{array}$ \\
\hline Case study 1 & $\begin{array}{l}\text { No. 120, } \\
\text { Armenian } \\
\text { Street }\end{array}$ & $\begin{array}{l}\text { Command } \\
\text { Base of } \\
\text { Tongmenghui } \\
\text { (since } 23 \text { May } \\
1909 \text { ) }\end{array}$ & $\begin{array}{l}\text { Dr. Sun Yat } \\
\text { Sen Museum } \\
\text { and Research } \\
\text { Center }\end{array}$ & I & Core \\
\hline Case study 2 & $\begin{array}{l}\text { Hutton Street, } \\
\text { Transfer } \\
\text { Street and } \\
\text { Clarke Street }\end{array}$ & $\begin{array}{l}\text { Three rows } \\
\text { of double- } \\
\text { storey terraced } \\
\text { houses and } \\
\text { shophouses }\end{array}$ & $\begin{array}{l}\text { Penaga Hotel } \\
\text { (45-room } \\
\text { hotel) }\end{array}$ & II & Buffer \\
\hline Case study 3 & $\begin{array}{l}\text { Nos. } 3,5 \text { and } \\
\text { 7, Fish Lane }\end{array}$ & $\begin{array}{l}\text { Shophouses } \\
\text { (street known } \\
\text { for salted fish } \\
\text { drying yard) }\end{array}$ & $\begin{array}{l}\text { Ongoing } \\
\text { renovation } \\
\text { work for } \\
\text { boutique hotel }\end{array}$ & II & Buffer \\
\hline
\end{tabular}

*Note for George Town Special Area Plan 2016 (SAP) Heritage Building Categories [2]:

- Category I: Buildings of exceptional interest and/or buildings and monuments declared as ancient and gazette under the Antiquities Act 1976.

- Category II: Buildings of special interest which warrant every effort being made to preserve them.

Source: Author, 2016.

\section{ADAPTIVE REUSE AND CHALLENGES}

Based on on-site observation, measured drawing exercise and building analysis, the study found that the three case studies applied adaptation which allows them to be used for a more relevant usage. However, the works still maintain the significant historical character of the buildings and their surroundings. Table 3 indicates some of the adaption works applied to the buildings followed by the discussion on the challenges faced by the building owners. 
Table 3: Adaptation works applied to the case studies.

\begin{tabular}{lll}
\hline Elevation & Plan & Axonometric section \\
\hline Case study 1 & $\begin{array}{l}\text { Building structures were } \\
\text { maintained and main } \\
\text { elements such as staircase } \\
\text { and air-well were restored }\end{array}$ & $\begin{array}{l}\text { Removable partitions } \\
\text { added between spaces to } \\
\text { accommodate new usage }\end{array}$ \\
\hline Elevation was restored
\end{tabular}

Case study 2

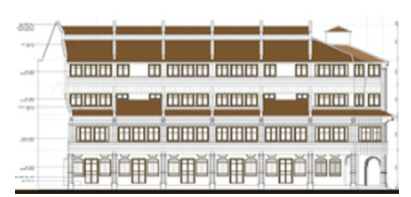

- The two-storey lower facade were maintained with two additional floor added at the rear portion

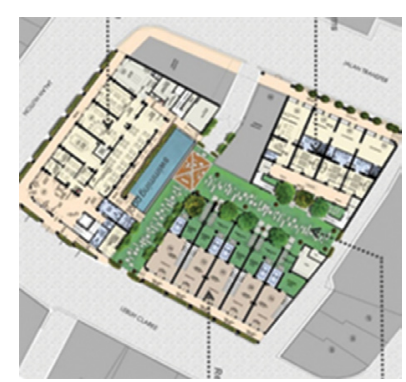

- Added accommodation rooms, offices and other facilities

- The 'Lanescape' in between the three blocks was added

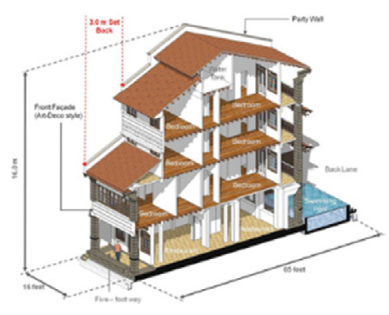

- Partition walls added to create accommodation rooms

- Additional floor added at the rear portion for additional space

\section{Case study 3}

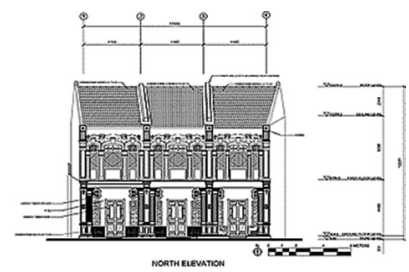

- Elevation was restored

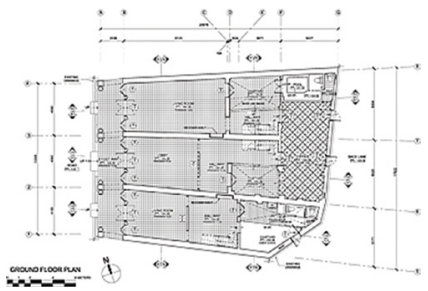

- The three units were linked by new internal passageway

- Building structures and main elements were maintained and restored

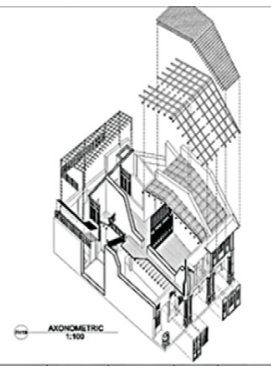

- Partition walls separated accommodation rooms and services

Source: Author, 2016. 


\subsection{Complying with current laws and regulations}

With the gazetting of the SAP in August 2016, MBPP enforces very strict rules in monitoring the sustainability management of the heritage zone in order to comply with the standards set by the World Heritage Committee [13]. It was mentioned that possible challenges for building owners in restoring their properties covered in the SAP area could be bounded by this regulation. The restoration or repair works involving heritage buildings has been regulated by MBPP using existing laws to ensure all works carried out comply fully with the conditions set. The gazetting of the SAP will tighten the enforcement for any future works.

Concurrently, proposals for new hotel will have to comply with current fire safety requirements from the fire department. In the case of Penaga Hotel, new fire-rated doors were required for accommodation rooms in compliance with regulations on sleeping accommodations and for fire compartmentation. Moreover, additional staircases for the Transfer Street block were required due to more floors being added and existing timber staircase were to be redesigned with gentler slope to meet current building bylaws.

The electrical service provider also required the hotel to provide a room for their equipment. This room needed to be on the ground floor and faces outside, thus taking away prime space from the already limited ground floor. The Penaga Hotel managed to accommodate the room at Hutton Street block and have it facing the back lane (Abdullah, A., Personal communication, 2012, Architect in-charge, Hijjas Kasturi Architects Sdn. Bhd., Kuala Lumpur, Malaysia).

\subsection{Lack of architectural aesthetics references}

All of the buildings had undergone architectural changes over time. Decisions on architectural aesthetics were based on old photographs and knowledge of artisan craftsmen which are on occasion quite difficult to obtain due to lack of records and time consuming. In many cases, the design of the ornaments motives was determined on-site, with frequent dialogues taking place between the artisan craftsmen and the owner. The artisan craftsmen would provide consultations on cultural references as they have very strong knowledge in this particular field, which many of the local architects and consultants did not have (Khoo, S.N., Personal communication, 29 November 2016).

\subsection{Lack of expertise on construction techniques and difficult site condition}

Since most of the buildings were built more than 50 years ago, the construction and repair techniques were very much dependent on the knowledge and skills of senior craftsmen. Investigations and inquiries on constructional detailing and appropriate materials to be used sometimes led to endless search, costly and also time consuming. In the case of Dr. Sun Yat Sen Museum, these craftsmen inherited the crafts from China and used appropriate methods to perform their work. Collective discussions among workers and owner often helped in determining the most suitable methods, materials and design that produced good outcomes. Some materials like roof tiles were imported from China to suit the architectural contexts of the building. When the materials arrived, the Chinese artisan craftsmen had to return home. The local contractors were hired to take over the job and very limited time was given to them to learn from the Chinese artisan craftsmen. As a result, some roof tiling work was not done with the same quality of craftsmanship, and minor defects were present (Khoo, S.N., Personal communication, 29 November 2016). 
Tight working space is also an issue. For example, in the case of Penaga Hotel, as there are new works to be done on existing buildings, in order not to damage the existing structures, works, especially those using big and heavy machines, need to be done carefully as the working areas available were limited and very tight. Careful planning is needed for this purpose (Abdullah, A., Personal communication, 2012, Architect in-charge, Hijjas Kasturi Architects Sdn. Bhd., Kuala Lumpur, Malaysia).

\subsection{Lack of knowledge on future repairs and maintenance work}

Maintenance of historical building is one of the most critical aspects of building conservation. Because of its delicate state and old age, maintenance is required from time to time to avoid further deterioration. Building owners and local contractors may not possess the knowledge and awareness of adopting appropriate methods in carrying out the maintenance and repair work. Khoo Salma (Khoo, S.N., Personal communication, 29 November 2016), when talking about Dr. Sun Yat Sen Museum, proposed that this issue could be addressed if knowledge transfer from the Chinese artisan craftsmen was done successfully. She hopes that more workshops and educational sessions would be organized to achieve effective knowledge transfer and sharing to ensure local architects and contractors would be able to carry out their work better.

\subsection{Safety and security}

Converting the shophouses into a hotel requires careful consideration with regard to safety and security. In Penaga Hotel, the need for privacy and security is important for hotel patrons at ground floor especially those facing the five-foot way at the main road. The same situation also applies to the back lanes. However, the back lane 'Lanescape' area (refer Section 5.7) is more secluded and less exposed to the public. A level of privacy was attained by having planter boxes at the edge of the walkway facing the roads. Open roller shutters were installed at the top opening of the colonnade so that they can be used at night. These measures did not go well with the local authorities, who insisted that the five-foot walkway is a public zone. It was resolved after the owner managed to convince the local authority that the plants added to the 'greening' of the hotel (Abdullah, A., Personal communication, 2012, Architect in-charge, Hijjas Kasturi Architects Sdn. Bhd., Kuala Lumpur, Malaysia).

\subsection{Complying with owners' needs and building functional needs}

Financially, the new development must be economically viable. The business owners invested in conversion of the shophouses for financial gain as well as to maintain the authentic heritage experience of the old George Town. The new development is to be done without destroying the heritage character of the buildings and its surrounding. This sometimes proved to be problematic as conservation of historic building is costly and requires serious commitment from the business owners for it to be successful.

In Penaga Hotel, the new facilities required are accommodation rooms, a restaurant, a bar, a spa and a swimming pool while the support facilities required are rooms such as manager's room, administration office, concierge, housekeeping room, security room and reception. In order to be economically viable, the hotel needs to have as many units as possible. This was achieved by adding more floors, up to the limit of height restriction and new building set back. Two more floors were added to the Hutton Street block and one more floor to the Transfer Street block. As an outcome, 32 units of deluxe rooms were incorporated in the Hutton 
Street block named the Hutton Rooms and 8 units on two floors in the Transfer Street block were designed and named the Transfer Suites. Another five double-storey units were incorporated in the Clarke Street block and named the Clarke Terrace House, making altogether 45 rooms in Penaga Hotel. In addition, the Hutton Rooms were made disable-friendly with the addition of a new lift within the main lobby area.

With the additional works such as the floors, staircases and a swimming pool, new foundations and footings were required. Bakau (mangrove) piles were used due to the soil conditions (Abdullah, A., Personal communication, 2012, Architect in-charge, Hijjas Kasturi Architects Sdn. Bhd., Kuala Lumpur, Malaysia). Careful planning on the design and cost of the new development is crucial in ensuring fruitful investment for the business owners.

\subsection{Contentious back lanes}

Typically for shophouses in Penang, the back lane is shared among them and defined as public realm. However, with the new development, some of the back lanes were redesigned to complement the new use of the building. In the Penaga Hotel, the three blocks have back lanes that are connected to each other, forming a T-shaped backyard for the hotel. This backyard houses the garden referred to as the 'Lanescape' and the swimming pool. Under the MBPP's regulations, the back lane of shophouses cannot be claimed as private property as it belongs to the public. As a solution, the owners occupied the back lanes under the Temporary Occupation of Land arrangement; nonetheless, annual charges are to be paid to the MBPP.

To provide privacy, the hotel put up a wall with unlocked doorway at the three ends of the 'Lanescape' so as to balance between the privacy of the hotel patrons and the freedom of the public to trespass. MBPP also requires that the hotel put up signage near the doorways at the outer walls to inform the public of the fact that the back lane is public area (Abdullah, A., Personal communication, 2012, Architect in-charge, Hijjas Kasturi Architects Sdn. Bhd., Kuala Lumpur, Malaysia) and also to engage more security personnel. The hotel, therefore, had to include extra expenditures in ensuring safety to its area.

\subsection{Building owners' conflict and inherited building issues}

Because of high investment cost for repairs and renovation of historic building, most of the owners jointly owned the property and operated the businesses. In the case of the shophouses at Fish Lane, which are intended to be a boutique hotel, the three partners had differing opinions on what to do with the building. As a result, the building underwent piecemeal renovation. The works on the building were also done without proper plans or permit. However, eventually, the owners decided to apply for Conservation Permit from MDPP. Upon realizing that there are fines to be paid due to non-compliance of regulations, the owners halted further works on the building (Fazil, M.A., Personal communication, November 2016, Technical Officer, Heritage Department, the Municipal Council of Penang (MPPP), Malaysia). The unresolved conflict among the partners led to the abandoning of the project and unsuccessful conservation of the building.

\section{CONCLUSION AND RECOMMENDATIONS}

Conservation of historic buildings had caused some challenges to business owners in the city of George Town, Penang. After 8 years of gaining the status of the UNESCO WHS, many of them are finding it difficult to meet the authority's guidelines and requirements while conserving the buildings for successful investment. There is a pressing need for the authorities 
to improve their collaboration with public and building owners as it appeared that they are adversarial and punitive in their dealing.

The public and building owners need to be better educated in the requirements, procedures and processes of development within the heritage zones, especially when tampering with heritage buildings. The authorities need to provide support in terms of expertise and financial incentives for building owners when embarking on heritage conservation works. Stakeholders and parties involved in the development of heritage buildings need to maintain proper communication to ensure clear understanding of responsibilities as well as cooperation throughout the process of development.

\section{REFERENCES}

[1] Penang State Government and Tourism Division, Penang Development Corporation, George Town, Penang, UNESCO World Heritage City.

[2] Town and Country Planning Department Pulau Pinang, Special Area Plan: Georgetown, Historic Cities of the Straits of Malacca, Town and Country Planning Department, Pulau Pinang, 2016.

[3] UNESCO, Melaka and George Town, Historic Cities of the Straits of Malacca, available at http://whc.unesco.org/en/list/1223 (accessed 27 December 2016).

[4] Heritage Department MBPP, Introduction, available at http://103.8.161.36:28132/web/ guest/jabatan-warisan (accessed 23 November 2016) (in Bahasa Malaysia).

[5] Heritage Department MBPP, Customer Charter, available at http://103.8.161.36:28132/ web/guest/jabatan-warisan (accessed 23 November 2016) (in Bahasa Malaysia).

[6] One Stop Center MBPP, Checklist for Pre-Application for Planning Permission, available at http://www.mbpp.gov.my/sites/default/files/mbpp/resources/download_forms/ osc_counter/trp_planning_pin4-_1.4.2015_mbpp.pdf (accessed 12 November 2016).

[7] One Stop Center MBPP, Checklist for Building Plans Approval, available at http:// www.mbpp.gov.my/sites/default/files/1_senarai_semak_pelan_bangunan_8.11.2016. pdf (accessed 12 November 2016).

[8] Tan, Y.W., Penang Shophouses. A Handbook of Features and Materials, Tan Yeow Wooi Culture \& Heritage Research Studio: Penang, 2015.

[9] Tan, Y.W., Shophouse/Townhouse, Asia perspective, Shophouse Conservation: Restoration and Adaptive Design in George Town, Penang, Tan Chin Tuan Foundation; National University Singapore, 2016.

[10] Khoo, S.N., Sun Yat Sen in Penang, Areca Books: Penang, 2008.

[11] Penang, Penang lang lah, available at http://teochiewkia2010.blogspot.my/2010/03/ street-names-of-georgetown-heritage.html (accessed 29 December 2016).

[12] Fish Lane, George Town, Penang, available at http:/www.penang-traveltips.com/fishlane.htm (accessed 28 December 2016).

[13] Mok, O., George Town World Heritage Special Area Plan to be gazetted August 1, Malay Mail Online, 5 July 2016, available at http://www.themalaymailonline.com/ malaysia/article/george-town-world-heritage-special-area-plan-to-be-gazetted-august1\#sthash.wIpfqAEZ.dpuf (accessed 20 November 2016). 